\title{
Efficient Energy and Financial Solutions for Residential Buildings in Algerian Saharan Climate
}

\author{
Muhammad Abdalkhalaq Chuayb Haddam ${ }^{1 *}$, Mohamed Kamal Cherier², Sidi Mohammed El Amine Bekkouche², \\ Maamar Hamdani², Sifia Belgherras ${ }^{3}$, Redouane Mihoub², Noceir Benamrane ${ }^{2}$ \\ ${ }^{1}$ University of Tlemcen, BP. 119, Tlemcen R.p. 13000, Algeria \\ ${ }^{2}$ Unité de Recherche Appliquée en Energies Renouvelables, URAER, Centre de Développement des Energies Renouvelables, \\ CDER, Ghardaïa 47133, Algeria \\ ${ }^{3}$ Université of Ghardaïa, BP 455, Airport road, Ghardaïa 47000, Algeria
}

Corresponding Author Email: haddam.abdalkhalaq@gmail.com

https://doi.org/10.18280/mmc_c.802-406

Received: 5 May 2019

Accepted: 22 October 2019

\section{Keywords:}

energy needs, compactness, thermal insulation, energy efficiency, low-energy house, financial solutions

\begin{abstract}
This paper compares two residential buildings, one conventional (inefficient uncomfortable) house and the other one low-energy in a residential block in Algerian Saharan climate. Deployed concepts are usually based on a more rational use of energy, a good insulation practice by optimizing thermal performance of opaque and transparent walls and eliminating thermal bridges, a passive heating of living spaces using solar gains, a better compactness and active aspects dedicated to lighting and heating domestic water.

In order to achieve comparative tests and emphasise the differences in energy and financial needs, an evaluation tool was developed to demonstrate that applying passive and active house design principles could be an alternative solution for energy-efficient buildings. The results indicate that the studied house is meeting the low-energy house design target of total energy requirement of less than $50 \mathrm{kWh} / \mathrm{m}^{2}$ year, the total energy saving was $79.13 \%$. In Saharan climate, the air cooling requires more elaborate techniques and is more complicated compared to the heating. For the Algerian state, it has been found that it is more appropriate to subsidize the relative cost of each integration system instead of subsidizing the kilowatt-hour price of electricity.
\end{abstract}

\section{INTRODUCTION}

The decrease in energy consumption and the use of renewable sources in the buildings sector permit the reduction of energy dependency and greenhouse gas emissions [1]. Thermal regulation is intended to limit the energy consumption of new buildings, regardless of their function. That is why some guidelines need to be considered. Primary energy consumption is concerned with the consumption for space heating, heating of domestic hot water, cooling and auxiliaries. Several research works provided opportunities of energy savings to get onto the path of sustainable energy. These study results are used to estimate expenditures and cost savings that can be envisaged. Various economic and financial indicators have shown the added benefit of reducing energy consumption in buildings.

The renovation of a residence is sometimes considered very advantageous. Six pairs of residential buildings were selected by [2] to focus their research on the energy classification, needs of energy consumption, indoor air quality and its dependence on energy renovation. In other studies [3], the energy saving potential was found to vary from 63 to $76 \%$ according to the climate zones when applying a number of passive strategies, including orientation, form, opening, sun shading devices and building materials. However, the elimination of excess thermal bridges could lead to energy savings of approximately $6 \%$ of annual heating and cooling energy needs [4].

The context should highlight, through a good bibliographic research, energy labelling systems using simplified methods to predict the required needs of buildings. Regarding studies that analyzed the energy performance, Fantozzi et al. [5] applied an indicator for the energy performance evaluation, the energy labelling and the two investigated buildings can be considered "low energy consumption buildings". In addition, Melo et al. [6] conducted a study based on a new approach to assess cooling energy demand and support a building energy labelling system. The labelling concepts aim also to inform consumers to promote the building efficiency and energy savings [7]. Limiting required energy needs will be essential to make possible a sustainable energy future. The actions that serve to minimise the use of energy and choose the most appropriate techniques are as follows: reduce transmission losses, ensure and provide a high thermal inertia, conceive an energy-efficient ventilation system, improve air-tightness in building, design an efficient heating system, optimize and select the best production and storage mode for heating and domestic hot water, implement an integrated passive cooling strategy and choose the best production method of renewable cooling, optimize natural lighting and reduce the thermal loads and integrate installations for producing renewable electricity. Through in-depth analysis by Terrill et al. [8] 
revealed that the largest opportunities for decrease in energy use come from proper maintenance and optimal start-up of heating, ventilation and air conditioning equipments. Indeed, different occupancy scenarios can lead to variable internal set points during day or week. In these cases, analysis results showed that the variation of the internal set point causes a clear change in energy needs of residential buildings. For existing multi-floor buildings with poor insulation, a decrease of $2^{\circ} \mathrm{C}$ in an internal apartment lead it to a reduction of effective energy consumption until $45 \%$, while adjacent apartments suffer an increase of up to $30 \%$ [9]. Ali-Toudert et al. [10] confirm that the pilot's house can go to a reduction of $55 \%$ for cooling and $89 \%$ for heating if this low-energy building is located in Algiers. If this house is subjected to the Ghardaiia climate, the energetic consumption corresponds to a saving of $29 \%$ for cooling and $94 \%$ for heating. In any case and in all circumstances, it is suggested that the priority is addressed to passive concepts to reduce energy demand [10$16]$.

This paper is focused on the building energy efficiency for both an inefficient house and a low-energy houses in a residential block simulated using an appropriate software. The simulation results were compared with the energy consumption recorded for a passive house in Ghardaïa, Algeria. The assessment criteria will be based on a welldefined lifestyle and occupancy scenario, the indoor comfort temperature and the required energy consumption expressed in $\mathrm{Kwh} /$ year $/ \mathrm{m}^{2}$.

Furthermore, Algeria continues to spend significant amounts to subsidize the energy price. This financing, which will be delivered as budget support to ordinary citizens, weighs heavily on the state budget. This was why successful solutions needed to be sought to resolve this unacceptable situation. The main originality of this research contribution consists in including some energy management operations and actions to rationalize energy use. It should be noted that the few existing works in these severe conditions (Saharan climate) do not deal properly with the problem. In addition, the asset of this contribution consists in applying a specific method to label any building and estimate energy needs. The combination of different approaches provided a new performing model.

\section{CASE STUDY}

\subsection{Climate data}

The simulations were carried out for one Algerian city: Ghardaïa (latitude $32.48^{\circ} \mathrm{N}$, longitude $3.80^{\circ} \mathrm{E}$ ) which has a hot, dry and desert climate. This region is noticeable by large temperature differences with a clarity index of 0.8 . The mean annual of global solar radiation measured on horizontal plane exceeds $20\left(\mathrm{MJ} / \mathrm{m}^{2}\right)$. The sunshine duration is more than 3000 hours per year, which promotes the use of solar energy in various fields [17]. The lowest sunshine duration is registered in December with 234.5 hours; the highest values were recorded during July with 337.3 hours. The average sunshine duration between 2000 and 2009 was 3391.20 hours per year i.e. approximately 9 hours per day. The annual average temperature is about $22.61^{\circ} \mathrm{C}$. Minimum temperatures of the coldest month are observed during the month of January with $5.5^{\circ} \mathrm{C}$, while maximum temperatures of the warmest month are observed during the month of July with $41.7^{\circ} \mathrm{C}$ [18]. The relative humidity is very low; it is of the order of $21.60 \%$ in July, reaching a maximum of $55.80 \%$ in January and an annual average of $38.33 \%$ [19].

\subsection{Description of the buildings}
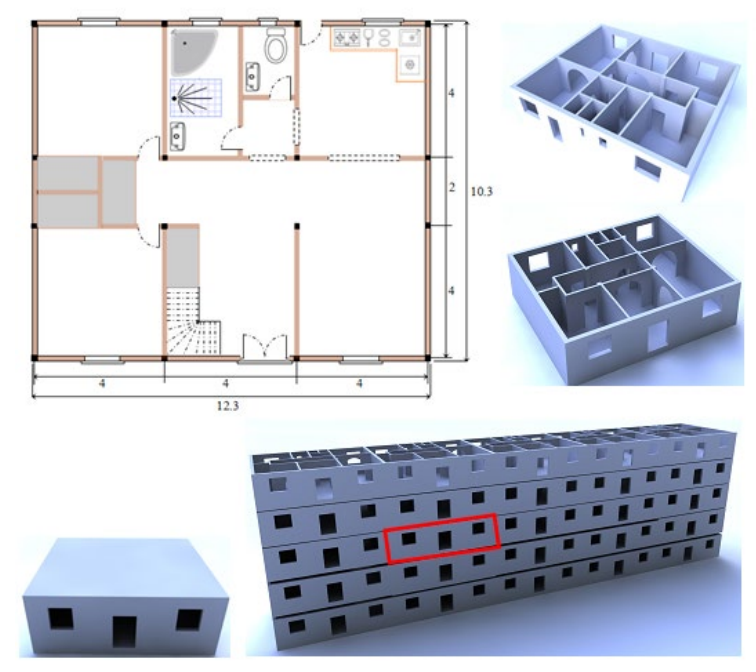

Figure 1. Descriptive planes, 2D and 3D Building modelling: single-family home and collective building which contains 25 stacked and juxtaposed apartments
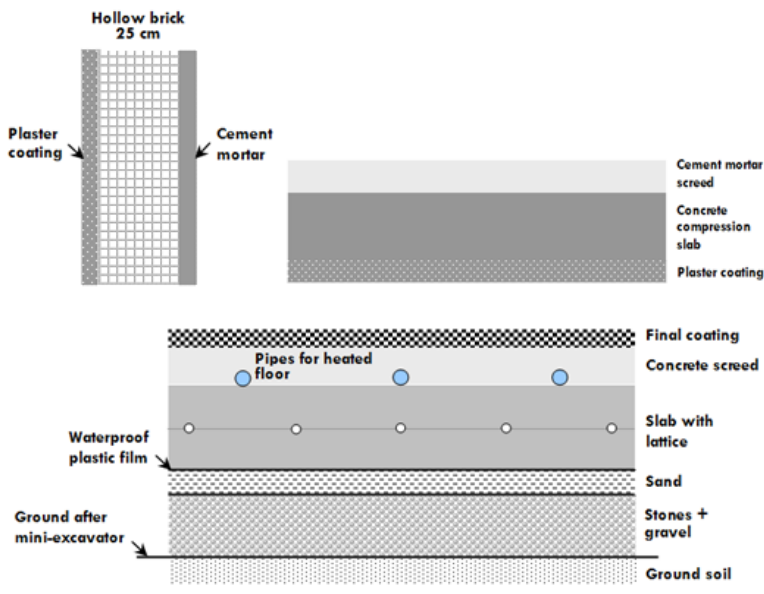

Figure 2. Masonry composition and structural elements configuration for a single-family home

The descriptive plans in figure 1 generally show some geometric properties of an energy-consuming house that will be compared to a single-family house of the same size in a collective building of 25 individual houses. This high-rise residential building is subject to some measures and architectural concepts including: a rational use of energy, a good thermal performance of opaque and transparent walls (walls, windows and doors) and a complete suppression of thermal bridges, an efficient passive heating of living spaces using solar gains and a better compactness. A single-family building with a total floor area of $126.69 \mathrm{~m}^{2}$ and a volume of $380.07 \mathrm{~m}^{3}$ is considered in this study. This surface area comprises an entrance hall, a living room, a kitchen, a bathroom, a toilet, two bedrooms and one stairwell. In the second case, the houses are without air conditioning (cooling and heating) and mechanical ventilation systems. Electricity is the main energy sources supplied to these buildings. The residents complained about the relative high winter and 
summer bills. This second building, conceived in a residential block, was selected to achieve minimum energy demand and better energy efficiency. This dwelling benefits from its improved building design; it promotes less heat loss per $\mathrm{m}^{2}$ and is thermally more efficient. In this collective building which contains 25 stacked and juxtaposed apartments, energy saving is important and more incentive. The different configurations of the roofs, ground and opaque walls are illustrated in Figure 2.

For the large building, an insulating layer of $10 \mathrm{~cm}$ was integrated outside the building elements, on the walls, the roofs and the ground. Single glazed windows are changed to a double wooden window with an air gap of more than 30 $\mathrm{mm}$. Metal doors are also changed by opaque wooden doors. Table 1 reflects and summarizes the most useful properties.

Table 1. U-values of the basic construction elements $\left(\mathrm{W} / \mathrm{m}^{2} \mathrm{~K}\right)$

\begin{tabular}{ccc}
\hline $\begin{array}{c}\text { Construction } \\
\text { elements }\end{array}$ & $\begin{array}{c}\text { Single- } \\
\text { family } \\
\text { home }\end{array}$ & $\begin{array}{c}\text { Low-energy house in the } \\
\text { high-rise residential building }\end{array}$ \\
\hline Walls & 1.44 & 0.31 \\
Floors & 1.57 & 0.32 \\
Roofs & 2.32 & 0.34 \\
Windows & 5.00 & 2.60 \\
Door & 5.80 & 3.50 \\
\hline
\end{tabular}

\section{ENERGY-BALANCE MODEL}

The energy balance has to deal with the physical parameters, thermal properties, building design, climatic conditions...etc. In the heating season and during interseasons, consumption and heating energy needs for buildings are given by the following formula [20-21]:

$$
Q_{\text {Needs }}=\left|Q_{\text {Envelop }}-\left(Q_{\text {Occup }}+Q_{E l c}\right)_{ \pm} Q_{\text {Solar }}\right|+Q_{D H W}+Q_{\text {tot_elec_ppl }}
$$

In the cooling season, equation 2 has to be used [20-21]:

$$
Q_{\text {Needs }}=Q_{\text {Envelop }}\left(Q_{\text {Occup }}+Q_{E l c}\right)+Q_{D H W}+Q_{\text {tot_elecppl }}+Q_{\text {Solar }}
$$

\subsection{Energetic needs due to the building thermal envelope}

Heating or/and cooling needs due to the building thermal envelope are defined by equation 3 [20-21]:

$$
Q_{\text {Enveloo }}=24 D P_{\text {envelop }} D j
$$

Detailed calculations are provided in reference [22]. DP envelop: envelope and ventilation heat losses (W/K). $\mathrm{Dj}$ : numbers of degree-days.

\subsection{Domestic hot water "DHW" Requirements}

To compute the DHW needs, the calculation should be based on the equation below. In any event, it is considered that the required volume of the hot water is 50 litters of hot water at $50^{\circ} \mathrm{C}$ per day per person. Energy needs for the DHW production is given by the following equation [20-21]:

$$
Q_{D H W}=1.162 \&_{D H W} N b_{o c c u p}\left(T_{D H W^{-}} T_{C W}\right)
$$

QDHw: energy needs required to produce DHW for one day, in $\mathrm{Wh}$

$\mathrm{V}_{\text {DHw: }}$ required volume of the hot water (litters)

$\mathrm{Nb}_{\text {occp }}$ : number of persons occupying the building

$\mathrm{T}_{\mathrm{DHW}}$ : temperature of the hot water at the filling point $\left({ }^{\circ} \mathrm{C}\right)$.

$\mathrm{T}_{\mathrm{CW}}$ : average monthly temperature of the cold water entering the storage tank or the DHW production coil (instant production).

\subsection{Internal heat gains}

The human being diffuses radiations in sensible (by the body at $37{ }^{\circ} \mathrm{C}$ ) and latent (by the production of water vapor via respiration and perspiration) heat form. Different values are given in the literature [20-21], the heat diffusion (W) from the occupants' activities are given by table 2 . The general equation that gives the values of internal gains is given by the following expression:

$$
Q_{\text {Occup }}=C p N b_{\text {occup }} D_{\text {pres/day }} N b_{\text {heated_da }}
$$

$\mathrm{Cp}$ : the amount of heat given off by occupant (W/occupant).

$\mathrm{D}_{\text {pres/day: }}$ the period of presence during the day (h/day).

$\mathrm{Nb}_{\text {heated_days: }}$ Number of heated days (days/year).

Table 2. Cp \& radiated heat per person [20-21]

\begin{tabular}{cc}
\hline Examples of activities & $\begin{array}{c}\text { Heat diffusion per } \\
\text { person (sensible and } \\
\text { latent) }\end{array}$ \\
\hline $\begin{array}{c}\text { Static sitting activities (read and write...) } \\
\text { Simple works that can be done either } \\
\text { sitting or standing, laboratory work, } \\
\text { typewriter... }\end{array}$ & $120 \mathrm{~W}$ \\
$\begin{array}{c}\text { Light physical activities } \\
\text { Medium to difficult bodily activities }\end{array}$ & $150 \mathrm{~W}$ \\
& $\begin{array}{c}190 \mathrm{~W} \\
\text { More than } 200 \mathrm{~W}\end{array}$ \\
\hline
\end{tabular}

The total amount of heat released by both equipment and lighting is determined according to the use and ignition mode of these electrical appliances. In this context, average values

\begin{tabular}{|c|c|c|c|c|c|}
\hline \multirow{2}{*}{$\begin{array}{l}\text { Type of } \\
\text { equipment }\end{array}$} & \multicolumn{4}{|c|}{$\begin{array}{c}\text { Duration (hours) and operating } \\
\text { power modes (Watts) }\end{array}$} & \multirow{2}{*}{$\begin{array}{l}\text { Energy } \\
\text { (Wh) }\end{array}$} \\
\hline & $\begin{array}{c}\text { Mode } \\
1\end{array}$ & $\begin{array}{l}\text { Number } \\
\text { of hours }\end{array}$ & $\begin{array}{l}\text { Mode } \\
2\end{array}$ & $\begin{array}{l}\text { Number } \\
\text { of hours }\end{array}$ & \\
\hline $\begin{array}{c}\text { LCD TV + } \\
\text { Integrated } \\
\text { demo }\end{array}$ & 20 & 19 & 78 & 5 & 1540 \\
\hline $\begin{array}{l}\text { Refrigerator } \\
\text { Lighting }\end{array}$ & \multicolumn{4}{|c|}{ The daily average is de $23 \mathrm{~W}$} & $\begin{array}{c}552 \\
1631.3\end{array}$ \\
\hline $\begin{array}{l}\text { Flat screen } \\
\text { computer }\end{array}$ & 32 & 2 & 186 & 4 & 808 \\
\hline Other & & al a Day & & & $\begin{array}{c}1200 \\
5731.3\end{array}$ \\
\hline
\end{tabular}
(default values) were adopted to define the internal loads in a building (table 3 ).

Table 3. Diffusion of heat by lighting and electrical equipment [20-21] 
Three input data must be taken into account according to Table 4

Table 4. Average energy consumption per day for electrical appliances [20-21]

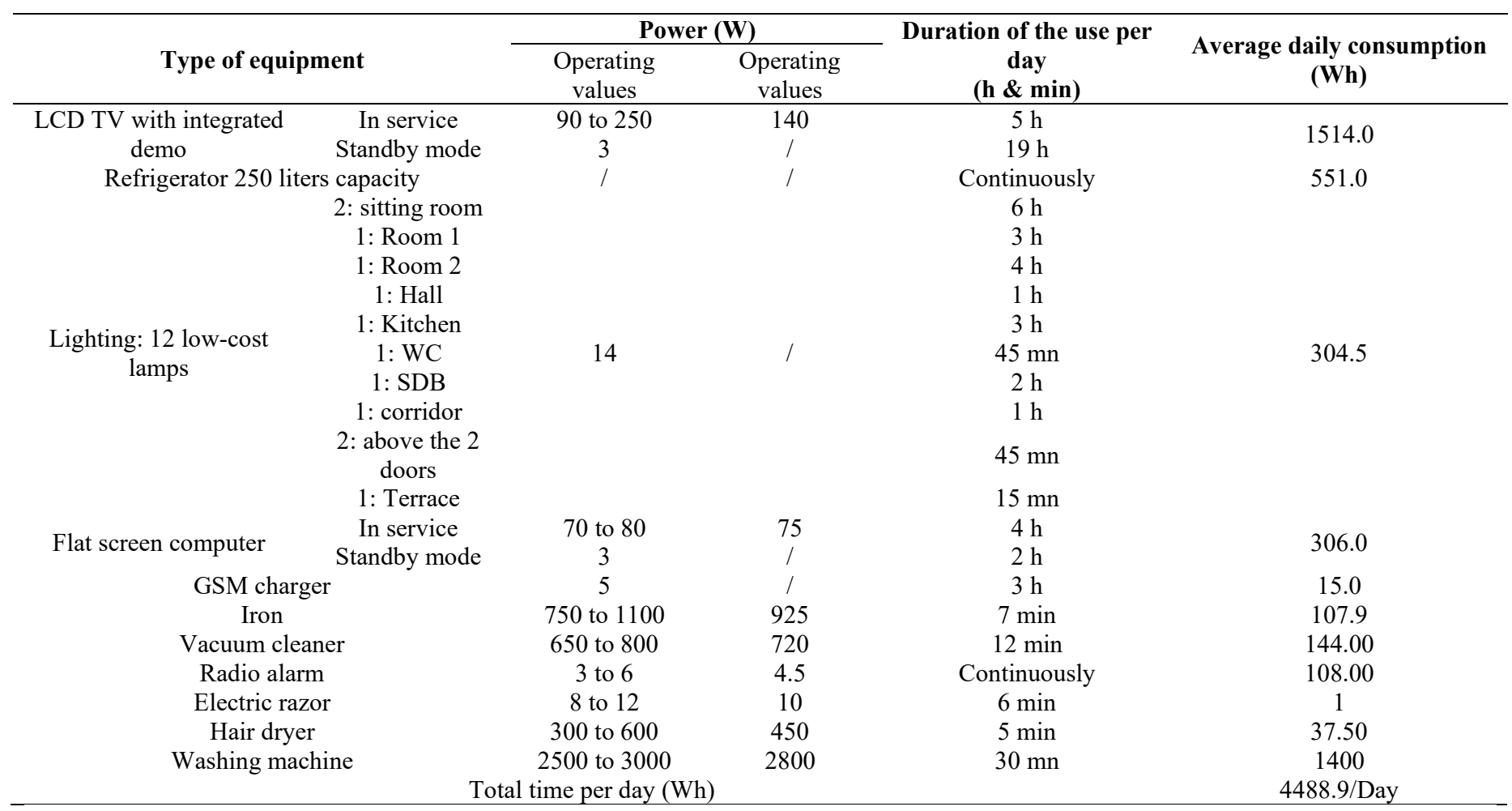

$P_{\text {elec_appl: }}$ the power of electrical appliances (W).

$\mathrm{Nb}_{\text {hours: }}$ : the number of hours when the device is in an operational state during the day.

$\mathrm{Nb}_{\text {days: }}$ : the number of days when the device is in an operational state during the year. Calculation, in kilowatthours, shall be as follows:

$$
Q_{\text {tot_elec_ppl }}=N b_{\text {hours }} N b_{\text {days }} \frac{P_{\text {elec_appl }}}{1000}
$$

\subsection{Passive solar gains}

The solar gains depend on the incident solar radiation, the orientation of the receiving surfaces and some characteristics such as: shading, transmission and absorption coefficients. This energy gain will be calculated according to the following equation $[20,22]$ :

$$
Q_{\text {Solar }}=\sum_{j} I_{S j} \sum_{n}\left(A F_{\text {Shad }} F_{\text {Red }} g\right)_{n j}
$$

The first sum is made on all orientations $j$; the second is applicable on all surfaces $\mathrm{n}$ in different orientations " $\mathrm{j}$ "

Is: solar irradiation per area unit $\left(\mathrm{Wh} / \mathrm{m}^{2}\right)$

$\mathrm{F}_{\text {Red }}$ : reduction factor for window frames, equal to the ratio of the transparent surface of the window to its total area; its value is set at 0.8

$\mathrm{F}_{\text {Shad}}$ : shading factor; its value is set at 0.7

$\mathrm{g}$ : solar factor of the bay window; its value is set at 0.8 for single-glazed windows.

\section{COMPARATIVE ANALYSIS OF ENERGY CONSUMPTION, ENERGETIC AND FINANCIAL ASPECT}

Before proceeding with the comparative study, it is preferable to draw up a summary table (5) giving some energy parameters of the two cases to be studied. The attention paid to the average outside air temperature of the month in question, monthly temperature of the cold water, passive solar gain, monthly values of internal gains, energetic hot water needs and the equivalent electricity consumption for one family home. The other selected input parameters are as follows: $\mathrm{T}_{\mathrm{DHW}}=50{ }^{\circ} \mathrm{C}, \mathrm{Cp}=150 \mathrm{~W}, \mathrm{~N}_{\text {boccp }}=5, \mathrm{D}_{\text {pres/day }}=$ $15 \mathrm{~h}$, the glass surface amount to about $95 \%$ of the window area, $\mathrm{F}_{\text {Shad }}=0.7$ for south orientation, $\mathrm{F}_{\text {Red }}=0.8$ and $\mathrm{g}=0.8$.

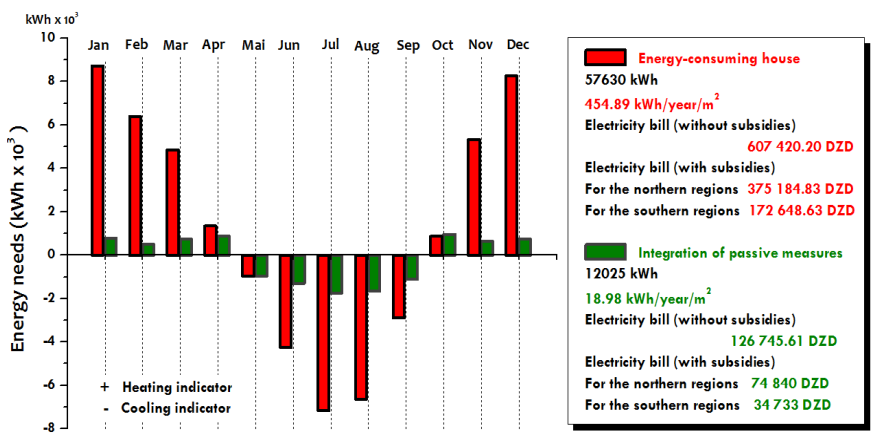

Figure 3. Monthly, annual final energy consumption and equivalent electric bills according to different subsidies from the Algerian state 
The approach is based on an in-depth study of the difference between the two dwellings. The similarity concerns the structural element dimensions and occupant lifestyles. The results that will be provided will therefore be expressed in $\mathrm{kWh} / \mathrm{m}^{2} / \mathrm{an}$, these unit values represent the average annual energy requirements even for a family home located in the large building. The calculation program designed for this purpose gives us the opportunity to calculate the annual heating energy demand, the annual cooling energy demand and the annual final energy consumption. Figure 3 provides results for calculating monthly and annual energy requirements of the two cases. In this regard, a comparison can be made between a detached single-family home and one another into a residential block.

The obtained results describe an energy use comparison between the previous dwellings. One is with high-energy consumption, while the second is specified as a building with more lower-energy consumption, which is based on the following passive and actives measures:

Table 4. Monthly values of the common energy parameters of all the cases to be studied

\begin{tabular}{|c|c|c|c|c|c|c|c|}
\hline & \multirow{2}{*}{$\begin{array}{l}\mathbf{T}_{\text {out }} \\
\left({ }^{\circ} \mathrm{C}\right)\end{array}$} & \multirow{2}{*}{$\begin{array}{l}\mathbf{T}_{\mathrm{CW}} \\
\left({ }^{\circ} \mathbf{C}\right)\end{array}$} & \multirow{2}{*}{$\begin{array}{c}\text { Q }_{\text {solar }} \\
(\mathbf{k W h})\end{array}$} & \multicolumn{2}{|c|}{$\begin{array}{c}\text { Internal heat gains } \\
(\mathrm{kWh})\end{array}$} & \multirow{2}{*}{$\begin{array}{l}\text { QDHW } \\
(\mathbf{k W h})\end{array}$} & \multirow{2}{*}{$\begin{array}{c}\text { QElec } \\
(\mathbf{k W h})\end{array}$} \\
\hline & & & & Qoccup & $Q_{\text {Elc }}$ & & \\
\hline January & 10.1000 & 7.0000 & 394.5667 & 348.7500 & 177.6703 & 387.5031 & 139.1559 \\
\hline February & 12.3000 & 9.0000 & 338.8108 & 315.0000 & 160.4764 & 333.7236 & 125.6892 \\
\hline March & 15.3000 & 11.5000 & 323.4353 & 348.7500 & 177.6703 & 346.9504 & 139.1559 \\
\hline April & 20.0000 & 13.0000 & 0 & 337.5000 & 171.9390 & 322.6770 & 134.6670 \\
\hline May & 24.5000 & 16.0000 & 0 & 348.7500 & 177.6703 & 306.3978 & 139.1559 \\
\hline June & 29.7000 & 19.0000 & 0 & 337.5000 & 171.9390 & 270.3510 & 134.6670 \\
\hline July & 33.4000 & 21.0000 & 0 & 348.7500 & 177.6703 & 261.3393 & 139.1559 \\
\hline August & 32.7000 & 20.0000 & 0 & 348.7500 & 177.6703 & 270.3510 & 139.1559 \\
\hline September & 27.8000 & 17.5000 & 0 & 337.5000 & 171.9390 & 283.4325 & 134.6670 \\
\hline October & 20.7000 & 15.0000 & 0 & 348.7500 & 177.6703 & 315.4095 & 139.1559 \\
\hline November & 14.4000 & 11.0000 & 354.1864 & 337.5000 & 171.9390 & 340.1190 & 134.6670 \\
\hline December & 10.7000 & 8.0000 & 348.3617 & 348.7500 & 177.6703 & 378.4914 & 139.1559 \\
\hline \multicolumn{6}{|c|}{ Total } & $3.816710^{3}$ & $1.638410^{3}$ \\
\hline
\end{tabular}

A more rational use of energy: the comfort is maintained for operating temperatures from $22^{\circ} \mathrm{C}$ to $25^{\circ} \mathrm{C}$ for the first house and from $21^{\circ} \mathrm{C}$ and $26^{\circ} \mathrm{C}$ for the second family home.

-A good insulation practice: by optimizing thermal performance of opaque and transparent walls (walls, windows and doors) and eliminating thermal bridges

-An efficient passive heating of living spaces using solar gains and

-A better compactness

-Domestic water heating using a solar water heater

-Lighting using a photovoltaic generator

Therefore, in Algeria the price of kilowatt-hour is competitive, converges to the tier of the average European price (18.64 $\mathrm{c} € / \mathrm{kWh})$. Algeria is one of the few countries in the world whose the price per kilowatt-hour is cheaper; the real price of $\mathrm{kWh}$ is $10.54 \mathrm{DZD}(1 €=134 \mathrm{DZD})$ [20]. Despite this state position, it still continues to subsidize electric bills by adopting a procedure adopted by SONELGAZ "National Electricity and Gas Company" [23$24]$.

The calculated values indicate that the annual energy consumption of the first single-family house, which keep comfort temperature between $22^{\circ} \mathrm{C}$ and $25^{\circ} \mathrm{C}$ in all zones (living room, kitchen, bathroom, toilet and hall), is set at $57630 \mathrm{kWh} /$ year. These energy needs are in conformity with an energy-intensive building which is equivalent to 454.89 $\mathrm{kWh} /$ year $/ \mathrm{m}^{2}$. The customer's payment of this invoice will require a sum of the order of 607420.2 DZD. But really, electric pricing for residential customers was benefited from a very important reduction of up to $38.58 \%$ for the North cities, and $71.70 \%$ for the southern region. The government has, moreover, multiplied the support measures to the residents of the southern Algeria. Southern residents received state support of $65 \%$ (not counting taxes) compared to the electricity bill in the North. These residents have benefited (to this day) from a state support of $65 \%$ (not counting taxes) compared to the electricity bill in the North.

For the second situation which is more favorable, corresponding to a family home of 5 occupants, stacked and juxtaposed in a collective building, energy needs have become highly important for economies: $12025 \mathrm{kWh} /$ year, i.e. $18.98 \mathrm{kWh} /$ year $/ \mathrm{m}^{2}$. Energy consumption decreased to $79.13 \%$ compared to the initial consumption. In this case, the state subsidies remain globally fixed; they are equivalent to $40.95 \%$ and $72.60 \%$ for the northern and southern regions respectively.

Furthermore, according to the results, the net energy demands for heating and cooling decrease fairly considerably. Figure 4 gives a performance comparison of ordinary and low-energy buildings. In recognition of this and by applying these measures, it was noted that the heating and cooling requirements decreased by $84.91 \%$ and $69.02 \%$ respectively. In warmer regions such as Ghardaïa, the air cooling requires more elaborate techniques and is more complicated compared to the heating, cooling needs are mainly due to the external solar and internal heat gains. The building envelope is the mean reason of this energy-intensive building, which has a major function in adapting thermal comfort variations. By integrating the previous concepts, the share of energy consumption due to the building envelope of total energy requirements will decrease from $92.27 \%$ to $55.56 \%$. On an annual basis, domestic hot water requirements represent $6.62 \%$ of the final consumption for the conventional house. In addition, the envelope is the main component in energyintensive buildings responsible for their high consumption, which is why the electrical requirements due to lighting and electrical appliances represent a small part $(2.84 \%)$ of the overall consumption. In this case, solar gains for passive heating contribute to a decrease of $14.63 \%$ of total needs.

The integration of passive architectural concepts, and by 
adding active solar systems to the building system, such as a photovoltaic system (12 PV panels: 2 rows of 6 PV modules with nominal power of 95Wc, 6 solar batteries: 3 rows of 2 batteries connected in series 100Ah, Solar Charge Controller MPPT $55 \mathrm{~A} 24 \mathrm{v}$ and Inverter 24V $3 \mathrm{KVA}$ ) which will supply electrical load requirements and ensure at least $80 \%$ of the electrical needs due to lighting and electrical appliances, and an evacuated tube solar water heating system with a 200-litre tank, this type of building can be considered as a construction of an energy label of type A "Low Energy Consumption Building".

$1^{\text {er }}$ case: Inefficient and uncomfortable house

$2^{\text {nd }}$ case: Building in residential block with passive and active measures

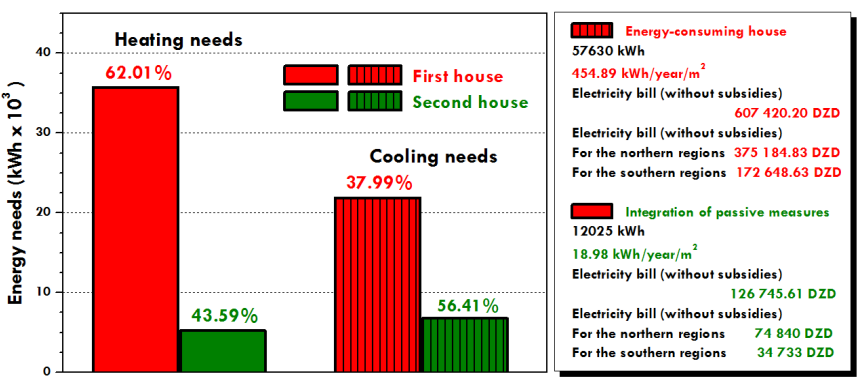

Figure 4. Performance comparison of ordinary and lowenergy buildings, energy needs during the cooling and heating seasons

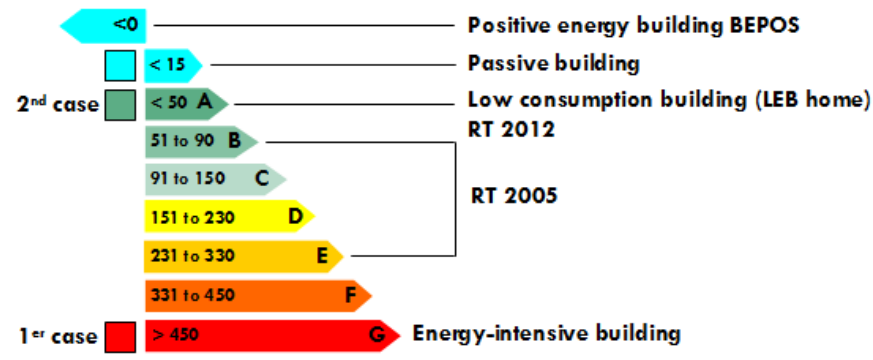

Figure 5. Building labelling scheme $\left(\mathrm{kWh} / \mathrm{m}^{2} /\right.$ year $)$

Thereafter, it is compulsory to study the techno-economic aspect, by optimizing the time of return on investment, which must therefore have a particular interest in these similar situations. Passive and active architecture may be incorporated in this building design; the method consists firstly in estimating the total cost resulting from the deployed techniques. Rational use of energy and passive heating of living spaces using solar gains will be ensured by respecting an exemplary lifestyle. The retained price of a polystyrene plate (5 $\mathrm{cm}$ thick layer and $2 \mathrm{~m}^{2}$ of surface area) is fixed at 600 DZD. The variation of the return time on investment, expressed by the number of months, is the ratio of the extra cost (the total cost with the incorporation of all concepts - the initial bill) multiplied by 12 and the annual financial gain which is defined by the difference between the initial bill and the energy bill in the second case (with deployed techniques). In Europe, the cost of the insulation works is scary and heavy (between 40 and $120 € / \mathrm{m}^{2}$ ), but the return on investment is really important [25]. By contrast, in Algeria, the prices of the works are cheaper compared to the European countries, we consider them between 1000 and $3000 \mathrm{DZD} / \mathrm{m}^{2}$. It is therefore the same thing, investment-return time remains globally important.

By retaining $1200 \mathrm{DZD} / \mathrm{m}^{2}$ as unit price of the insulation works (workers, transportation and other expenses), the results describing the financial aspect will be detailed as follows:

- The initial unsubsidised electricity bill was estimated at 607420.20 DZD.

- The annual non-subsidized bill required for the second case, to ensure indoor comfort in all areas between $21^{\circ} \mathrm{C}$ and $26{ }^{\circ} \mathrm{C}$, amounts to $126745.61 \mathrm{DZD}$

- The annual financial gain amounts to 480674.59 DZD, representing $79.13 \%$ of the initial electricity bill

- The cost of the insulating material is 233388 DZD, the total cost of the insulation works is 466776 DZD, this implies that the total financial charge after insulation is 826909.61 DZD

- In the photovoltaic system, total cost will be billed at 40000 DZD per kilowatt-hour, which is equivalent to a total cost of $179556 \mathrm{DZD}$

- The price of the plan water heater is fixed at $90000 \mathrm{DZD}$,

- The additional cost is equal to 489045.41 DZD, presents exactly $80.50 \%$ of the initial electrical bill

In recognition of this, it has been found that the investment-return time was estimated at only 12 months and 6 days.

For a net purchase price of $3000 \mathrm{DZD} / \mathrm{m}^{2}$, the investmentreturn time in this case did not exceed 36 months. These results strongly encourage and motivate citizens to implement some initiatives to rationalize the energy use and apply the previous identification techniques. These short periods are due mainly to the energy bill which is very high in the absence of adequate insulation. On the other hand, the heavy initial bills and the low costs of the insulation process (thermal insulation materials price and the cost of the insulation works) compared to the energy bills have caused a lower extra cost compared to the financial gain related to this operation.

The calculated values indicate that the annual energy consumption of the first single-family house, which keep comfort temperature between $22^{\circ} \mathrm{C}$ and $25^{\circ} \mathrm{C}$ in all zones (living room, kitchen, bathroom, toilet and hall), is set at $57630 \mathrm{kWh} /$ year. These energy needs are in conformity with an energy-intensive building which is equivalent to 454.89 $\mathrm{kWh} / \mathrm{year} / \mathrm{m}^{2}$. The customer's payment of this invoice will require a sum of the order of 607420.2 DZD. But really, electric pricing for residential customers was benefited from a very important reduction of up to $38.58 \%$ for the North cities, and $71.70 \%$ for the southern region. The government has, moreover, multiplied the support measures to the residents of the southern Algeria. Southern residents received state support of $65 \%$ (not counting taxes) compared to the electricity bill in the North. These residents have benefited (to this day) from a state support of $65 \%$ (not counting taxes) compared to the electricity bill in the North.

For the second situation which is more favorable, corresponding to a family home of 5 occupants, stacked and juxtaposed in a collective building, energy needs have become highly important for economies: $12025 \mathrm{kWh} /$ year, i.e. $18.98 \mathrm{kWh} /$ year $/ \mathrm{m}^{2}$. Energy consumption decreased to $79.13 \%$ compared to the initial consumption. In this case, the state subsidies remain globally fixed; they are equivalent to $40.95 \%$ and $72.60 \%$ for the northern and southern regions respectively.

If state subsidies are taken into account, we will find that 
the invoices corresponding to an energy-intensive house will be fixed at 373077.49 DZD (reduction of up to $38.58 \%$ ) for the North cities and 171899.92 DZD (reduction of up to $71.70 \%$ ) for the southern region. In addition, the annual nonsubsidized bill required to ensure indoor comfort in all areas between $21{ }^{\circ} \mathrm{C}$ and $26{ }^{\circ} \mathrm{C}$, amounted to 126745.61 DZD for of a low energy home. This bill is lower and sufficiently below the previous bills for an energy-intensive building, whilst always respecting financial subsidies. It therefore means that the conservation of our natural resources, will lead us to require the subsidy of financial expenses related to the architectural concepts works (more precisely extensive heat insulation) instead of subsidising the kilowatt-hour price of electricity.

In conclusion, buildings with low energy consumption will provide a greater opportunity to adapt to climate change; low-energy future buildings set an energy consumption of less than $50 \mathrm{kWh}$ of primary energy $/ \mathrm{m}^{2} /$ year. It is a building construction with very low $\mathrm{CO}_{2}$ release rates and therefore respectful of the environment. According to a number of bibliographic sources, low-energy buildings "LEB houses" are $10 \%$ to $15 \%$ more expensive than an apartment building in conformity with the French regulation RT 2005, and are still about $20 \%$ higher than a traditional residential construction.

The proposed financial studies based on the cost estimates may be requested to confirm the previous details. Table 6 gives an approximate comparison between an energyintensive residential building and a low-energy building in a residential block of 25 apartments, as shown in figure 1 . The selling price of the LEB house will be deducted by dividing the selling price of the entire residential block on 25 .

Table 6. Comparative estimate between the two types of buildings

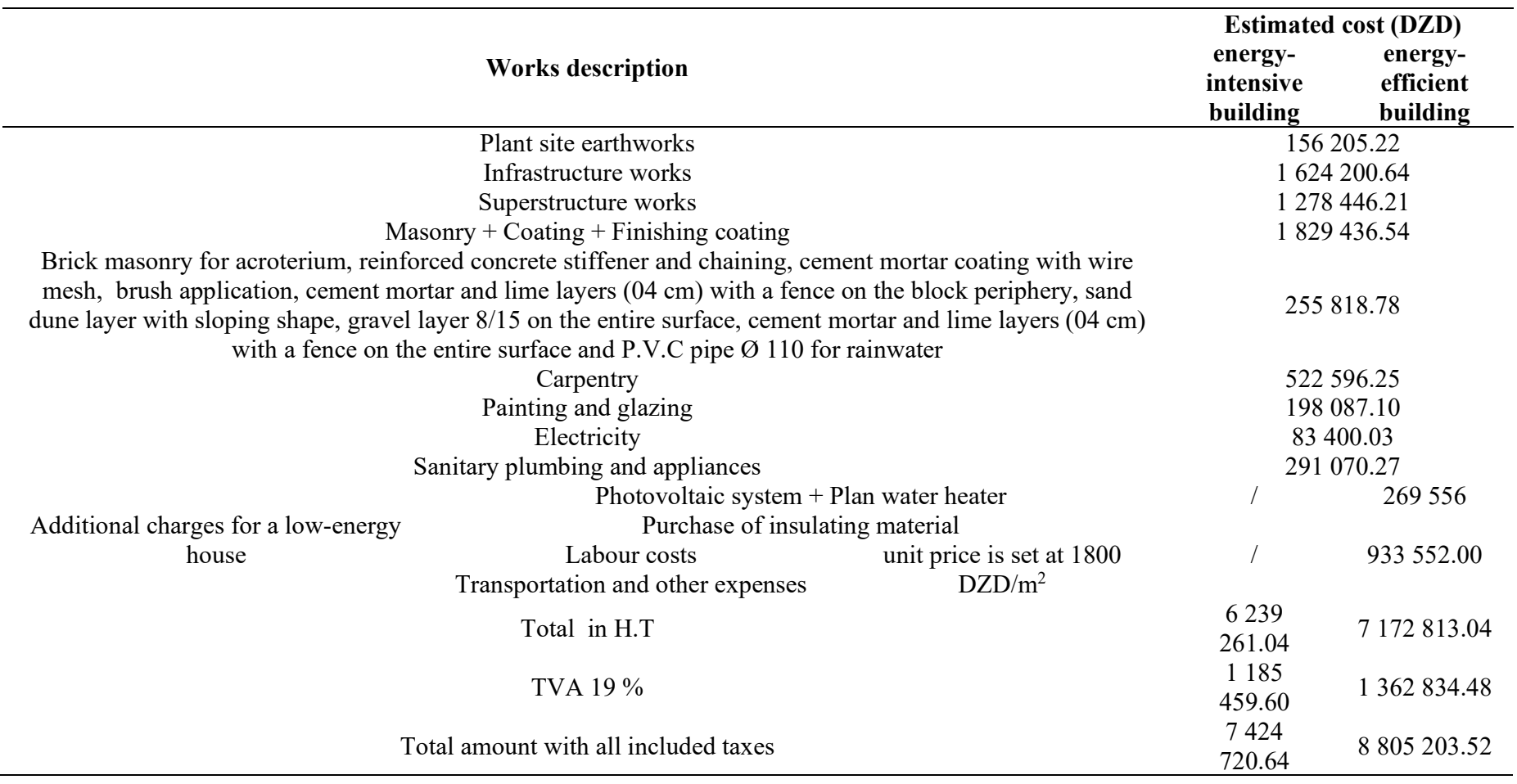

In this case study, this low-energy building costs $18.59 \%$ more expensive compared to conventional houses.

\section{CONCLUSION}

In this research work, the evaluation of energy needs on the basis of an accurate model was conducted. Determining an energy label requires collecting some climatic data for a building over a period of minimum 12 months. By implementing this recent modelling approach, and before committing to construct a residential building, it will be possible to issue an energetic label by providing parameters, occupancy scenarios, lifestyle and all necessary data. The present work focuses essentially on a detailed analysis of energy needs. Assigning labels for buildings involves a step forward, particularly for Saharan regions which are characterized by a dry, hot and desert climate. The diagnosis was considered two cases: the case of an inefficient and uncomfortable house whereas the second case corresponds to a low-energy family building in a residential block. Their concepts are based on a more rational use of energy, a good insulation practice: by optimizing thermal performance of opaque and transparent walls (walls, windows and doors) and eliminating thermal bridges, a passive heating of living spaces using solar gains and a better compactness.

As a result of those findings, the first studied building is an energy-intensive house; energy needs were more than 450 $\mathrm{KWh} / \mathrm{m}^{2} /$ year "type $\mathrm{G}$ ". The building envelope is the mean reason of this energy-intensive building, which has a major function in adapting thermal comfort variations. External insulation applied to the opaque components is the most effective solution because it eliminates thermal bridges and maintains the thermal inertia of interior walls despite the fact that it is the most expensive.

With regard to previous measures, this type of construction will join the buildings that have an energy label of "type A". In warmer regions such as Ghardaiia, energy needs have become highly important for economies $\left(18.98 \mathrm{kWh} / \mathrm{year} / \mathrm{m}^{2}\right)$, energy consumption decreased to $79.13 \%$ compared to the first case. It was noted that the heating and cooling 
requirements decreased by $84.91 \%$ and $69.02 \%$ respectively. The air cooling requires more elaborate techniques and is more complicated compared to the heating. The share of energy consumption due to the building envelope of total energy requirements will decrease from $92.27 \%$ to $55.56 \%$. By adding active solar systems to the building system, such as, a photovoltaic system which will ensure at least $80 \%$ of the electrical needs due to lighting and electrical appliances, and an evacuated tube solar water heating system with a 200litre tank, this type of building can be considered as a passive construction.

However, according to the techno-economic study, it therefore means that the conservation of our natural resources, will lead us to require the subsidy of financial expenses related to the architectural concepts works (more precisely extensive heat insulation) instead of subsidising the kilowatthour price of electricity. Building with low energy consumption is a construction with very low $\mathrm{CO}_{2}$ release rates and will provide a greater opportunity to adapt to climate change. For an unit price set at $1800 \mathrm{DZD} / \mathrm{m}^{2}$, this low-energy building costs $14.96 \%$ more expensive compared to conventional houses. This is mainly due to the use of specific materials for the house's heat insulation.

Future comprehensive studies and the focus of this work present several avenues for future research in residential buildings, including as example: influence of compactness for different shapes of building, contribution of direct solar gain and orientation, integration of heating, cooling, ventilation and other renewable energy systems.

\section{REFERENCES}

[1] Kouidri, M.A., Bessissa, L., Mahi, D., Hadjadj, A. (2019). Experimental environmental study of atmospheric emissions in the urban area of the industrial city of Hassi R'mel. Modelling, Measurement and Control C, 80(1): 1-4. https://doi.org/10.18280/mmc c. 800101

[2] Ghasemi, Z., Esfahani, M.A., Bisadi, M. (2015). Promotion of urban environment by consideration of human thermal \& Wind comfort: A literature review. Asian Conference on Environment-Behaviour Studies, Tehran, Iran, Procedia Social and Behavioral Sciences 201: $397-408$ https://doi.org/10.1016/j.sbspro.2015.08.193

[3] Cohen, P., Potchter, O., Matzarakis, A. (2012). Daily and seasonal climatic conditions of green urban open spaces in the Mediterranean climate and their impact on human comfort. Building and Environment, 51: 285295. https://doi.org/10.1016/j.buildenv.2011.11.020

[4] Taleghani, M., Tenpierik, M., Kurvers, S., Dobbelsteen, A. (2013). A review into thermal comfort in buildings. Renewable and Sustainable Energy Reviews, 26: 201215. https://doi.org/10.1016/j.rser.2013.05.050

[5] Daneshvar, M.R.M., Bagherzadeh, A., Tavousi, T. (2013). Assessment of bioclimatic comfort conditions based on physiologically equivalent temperature (PET) using the RayMan Model in Iran. Central European Journal of Geosciences, 5(1): 53-60. https://doi.org/10.2478/s13533-012-0118-7

[6] Salata, F., Golasi, I., Vollaro, R., Vollaro, A. (2016). Outdoor thermal comfort in the Mediterranean area, a transversal study in Rome, Italy. Building and
Environment, 96: 46-61. https://doi.org/10.1016/j.buildenv.2015.11.023

[7] Algeciras, J.A.R., Matzarakis, A. (2015). Quantification of thermal bioclimate for the management of urban design in Mediterranean climate of Barcelona, Spain. International Journal of Biometeorology, 60(8): 126170. https://doi.org/10.1007/s00484-015-1121-8

[8] Terrill, T.J., Rasmussen, B.P. (2016). An evaluation of HVAC energy usage and occupant comfort in religious facilities. Energy and Buildings, 128: 224-235. https://doi.org/10.1016/j.enbuild.2016.06.078

[9] Semprini, G., Barbieri, D., Gober, A., Zandi, F. (2015). Effect of occupant behavior and control systems on the reduction of energy needs of residential buildings. $6^{\text {th }}$ International Building Physics Conference, IBPC 2015. Energy Procedia, 78: 633-638. https://doi.org/10.1016/j.egypro.2015.11.044

[10] Ali-Toudert, F., Weidhaus, J. (2017). Numerical assessment and optimization of a low-energy residential building for Mediterranean and Saharan climates using a pilot project in Algeria. Renewable Energy, 101: 327346. https://doi.org/10.1016/j.renene.2016.08.043

[11] Imessad, K., Derradji, L., Ait Messaoudene, N., Mokhtari, F., Chenak, A., Kharchi, R. (2014). Impact of passive cooling techniques on energy demand for residential buildings in a Mediterranean climate. Renewable Energy, 71: 589-597. https://doi.org/10.1016/j.renene.2014.06.005

[12] Liang, X., Wang, Y., Royapoor, M., Wu, Q., Roskilly, T. (2017). Comparison of building performance between conventional house and passive house in the UK. $9^{\text {th }}$ International Conference on Applied Energy, ICAE2017, Cardiff, UK. Energy Procedia, 142: 18231828. https://doi.org/10.1016/j.egypro.2017.12.570

[13] Audenaert, A., De Cleyn, S.H., Vankerckhove, B. (2008). Economic analysis of passive houses and lowenergy houses compared with standard houses, Viewpoint. Energy Policy, 36: 47-55. https://doi.org/10.1016/j.enpol.2007.09.022

[14] Dan, D., Tanasa, C., Stoian, V., Brata, S., Stoian, D., Nagy Gyorgy, T., Florut, S.C. (2016). Passive house design - An efficient solution for residential buildings in Romania. Energy for Sustainable Development, 32: 99109. https://doi.org/10.1016/j.esd.2016.03.007

[15] Sadineni, S.B., Madala, S., Boehm, R.F. (2011). Passive building energy savings: A review of building envelope components. Renewable and Sustainable Energy Reviews, 15: 3617-3631. https://doi.org/10.1016/j.rser.2011.07.014

[16] Mihai, M., Tanasiev, V., Dinca, C., Badea, A., Vidu, R. (2017). Passive house analysis in terms of energy performance. Energy and Buildings, 144: 74-86. http://dx.doi.org/doi:10.1016/j.enbuild.2017.03.025

[17] Gairaa, K., Bakelli, Y. (2011). An overview of global solar radiation measurements in Ghardaïa area, south Algeria. International Journal of Energy and Environment, 2(2): 255-260.

[18] Bekkouche, S.M.A., Benouaz, T., Hamdani, M., Cherier M.K., Yaiche, M.R., Benamrane, N. (2017). Diagnosis and comprehensive quantification of energy needs for existing residential buildings under Sahara weather conditions. Advances in Building Energy Research, 11(1): 37-51. 
[19] Bekkouche, S.M.A., Benouaz, T., Cherier, M.K., Hamdani, M., Yaiche, M.R., Khanniche, R. (2013). Influence of building orientation on internal temperature in Saharan climates, building located in Ghardaïa region (Algeria). International Scientific Journal, Thermal Science, 17(2): 349-364. https://doi.org/10.2298/TSCI110121112B

[20] Bendara, S., Bekkouche, S.M.A., Benouaz, T., Belaid, S., Hamdani, M., Cherier, M.K., Boutelhig, A., Benamrane, N. (2019). Energy efficiency and economic insulation thickness according to the compactness measure, case of a studio apartment under Saharan weather conditions. Journal of Solar Energy Engineering, 141(4): 041011. https://doi.org/10.1115/1.4042455

[21] Belgherras, S., Bekkouche, S.M.A., Benouaz, T., Benamrane, N. (2017). Prospective analysis of the energy efficiency in a farm studio under Saharan weather conditions. Energy and Buildings, 145: 342353. https://doi.org/10.1016/j.enbuild.2017.04.030
[22] Bekkouche, S.M.A., Benouaz, T., Hamdani, M., Cherier, M.K., Yaiche, M.R., Benamrane, N. (2017). Diagnosis and comprehensive quantification of energy needs for existing residential buildings under Sahara weather conditions. Advances in Building Energy Research, 11(1): 37-51. https://doi.org/10.1080/17512549.2015.1119059

[23] Compagnie Algérienne chargée de la production, du transport et de la distribution de l'électricité et du gaz en Algérie. http://www.sonelgaz.dz/?page=article\&id=4, accessed on Jan. 10, 2019.

[24] Ministère de l'énergie, Commission de Régulation de l'Electricité et du Gaz CREG. https://www.creg.dz/index.php/consommateurs/estimervotre-facture, accessed on Jan. 10, 2019.

[25] Toiture, sol ou murs, intérieur ou extérieur: tout savoir sur le prix de l'isolation thermique.www.calculeo.fr/Subventions/Isolationthermique/Prix, accessed on Jan. 10, 2019. 